\title{
Blasfemie in de huidige context ${ }^{*}$
}

\author{
Jasper Doomen \& Mirjam van Schaik
}

\section{Inleiding}

In dit artikel staat een thema centraal dat niet alleen een lange geschiedenis heeft, maar vooral recentelijk op een sterke belangstelling mag rekenen: godslastering. In Nederland heeft de discussie over de waarde hiervan zich toegespitst op het verbod hiervan. Dit verbod is op basis van een wetswijziging van 23 januari 2014 komen te vervallen; deze wijziging is vanaf 1 maart 2014 van kracht. Dit artikel is erop gericht de discussie te verbreden, zodat kan worden nagegaan hoe wenselijk deze wijziging is in het licht van de relevante overwegingen om het verbod te schrappen. In paragraaf 1 wordt een korte historische schets geboden om duidelijk te maken wat de basis van de tot voor kort geldende wetgeving is. Deze context maakt tegelijk duidelijk wat er op het spel staat voor degenen wier belangen gediend worden met het verbod.

In paragrafen 2 en 3 wordt aangeven hoe godsdienstige opvattingen zich verhouden tegenover niet-godsdienstige, waarbij de vraag aan de orde komt of aan het gelijkheidsbeginsel afbreuk wordt gedaan als godsdienstige posities bijzondere bescherming genieten. In paragraaf 4 wordt aandacht besteed aan de uiteenlopende belangen die met het verbod op godslastering gediend worden. Het gaat dan om de vrijheid van meningsuiting tegenover het belang van de gelovigen. Hierbij wordt aansluiting gezocht bij het schadebeginsel van John Stuart Mill. Vervolgens wordt in paragraaf 5 de motie-Schrijver c.s. geëvalueerd, waarna wordt onderzocht of een alternatief wetsartikel het 'gemis' dat ontstaat door de wetswijziging kan opvangen en hoe wenselijk het is als dat gebeurt. Het is duidelijk dat een onderwerp als het onderhavige de landsgrenzen overschrijdt. In paragraaf 6 wordt daarom aandacht besteed aan de internationale dimensie. Hierin zal gewezen worden op de discussies die op dat niveau een rol spelen en zal worden aangetoond dat Nederland in deze kwestie een markante rol speelt.

\section{De wetsgeschiedenis van blasfemie}

Het is duidelijk dat godslastering niet steeds op dezelfde manier is beoordeeld. De middeleeuwse filosoof en theoloog Thomas van Aquino stelt dat godslastering beschouwd moet worden als een van de ernstigste zonden van de mens. Godslastering is een doodzonde, omdat de intentie gericht is op het krenken van Gods eer, een zonde waaraan zwaarder gewicht moet worden toegekend dan aan het

* Wij willen graag Paul Cliteur bedanken voor zijn commentaar op dit artikel. Het onderwerp van deze bijdrage wordt deels besproken in ons artikel in NJB 2014/30. 
opzettelijk doden van een mens. ${ }^{1}$ In de lijn van Thomas' gedachtegoed wordt tot in de negentiende eeuw godslastering in Nederland gekwalificeerd als strafwaardig. In de Verlichting wordt dit gewijzigd en na de invoering van de Code Pénal in 1811 en het Nederlandse Wetboek van Strafrecht in 1881 maakt het delict niet langer deel uit van het strafrecht. ${ }^{2}$ In 1932 komt hier weer verandering in; het godslasteringsverbod keert terug in de wet om strafrechtelijk op te kunnen treden tegen antireligieuze uitingen vanuit communistische hoek. ${ }^{3}$ In het bijzonder het artikel 'Weg met het Kerstfeest', dat in 1930 verschijnt in De Tribune, het blad van de Communistische Partij Holland, leidt tot de nodige maatschappelijke beroering en onrust. Hierin is het volgende opgenomen: 'O, hij is een bijzonder groot genot, die goeie God. (...) Hij marcheert voorop in de oorlogsvoorbereiding. Hij verleent glans aan de lastercampagne tegen de Sowjet-Unie. (...) Hij is het symbool van de verdomming der massa's. (...) Hij is de beschermheilige van de moordenaars in de werkverschaffing.' En 'Christus op de mestvaalt, De Heilige Maagd in den stal, De Heilige Vaders naar den duivel, Leve de stem van het kanon, het kanon der proletarische revolutie (...). ${ }^{4}$ In de navolgende weken verschijnen in hetzelfde blad een artikel van soortgelijke strekking en diverse spotprenten waarin God onder andere wordt afgebeeld als gifmenger. Deze 'propaganda' is voor de voormalige minister van Justitie Donner reden om de 'Lex Donner', het wetsvoorstel dat 'smalende godslastering' strafbaar stelt, in te dienen bij de Tweede Kamer. ${ }^{5} \mathrm{Na}$ een uitvoerige parlementaire behandeling worden artikelen 147, 147a en 429bis van het Wetboek van Strafrecht (Sr) ingevoerd. De artikelen zoals die tot voor kort in het Wetboek van Strafrecht waren opgenomen, luiden als volgt:

\section{Artikel 147}

Met gevangenisstraf van ten hoogste drie maanden of geldboete van de tweede categorie wordt gestraft:

1. hij die zich in het openbaar, mondeling of bij geschrift of afbeelding, door smalende godslasteringen op voor godsdienstige gevoelens krenkende wijze uitlaat;

2. hij die een bedienaar van de godsdienst in de geoorloofde waarneming van zijn bediening bespot;

3. hij die voorwerpen aan een eredienst gewijd, waar en wanneer de uitoefening van die dienst geoorloofd is, beschimpt.

1 Thomas Aquinas, Summa Theologiae 2a2ae. Opera Omnia, deel 8 (Rome: Ex Typographia Polyglotta S. C. de Propaganda Fide, 1895 [1274]), q. 13, art. 4.

2 Koos Plooy, Strafbare godslastering (Amsterdam: Buijten en Schipperheijn, 1986), 25; Bas van Stokkom, Henny Sackers en Jean-Pierre Wils, Godslastering, discriminerende uitingen wegens godsdienst en haatuitingen. Een inventariserende studie, WODC Onderzoek en Beleid 248 (Den Haag: Boom Juridische uitgevers, 2007), 45, 85-88.

3 Plooy, Strafbare godslastering, 28, 30; Kamerstukken II 2009/10, 32203, 4, 2.

4 'Weg met het Kerstfeest,' De Tribune, 24 december 1930.

5 Jacob de Ruiter, 'Drie maal godslastering in het parlement,' Jaarboek parlementaire geschiedenis 2005: God in de Nederlandse politiek (Den Haag: Sdu Uitgevers, 2005), 41-43. 


\section{Artikel 147a}

1. Hij die een geschrift of afbeelding waarin uitlatingen voorkomen die, als smalende godslasteringen, voor godsdienstige gevoelens krenkend zijn, verspreidt, openlijk tentoonstelt of aanslaat of, om verspreid, openlijk tentoongesteld of aangeslagen te worden, in voorraad heeft, wordt, indien hij weet of ernstige reden heeft om te vermoeden dat in het geschrift of de afbeelding zodanige uitlatingen voorkomen, gestraft met gevangenisstraf van ten hoogste twee maanden of geldboete van de tweede categorie.

2. Met dezelfde straf wordt gestraft hij die, met gelijke wetenschap of een gelijke reden tot vermoeden, de inhoud van een zodanig geschrift openlijk ten gehore brengt.

\section{Artikel 429bis}

Hij die op een van de openbare weg zichtbare plaats woorden of afbeeldingen stelt of gesteld houdt, die, als smalende godslasteringen, voor godsdienstige gevoelens krenkend zijn, wordt gestraft met hechtenis van ten hoogste een maand of geldboete van de tweede categorie.

Ondanks het bestaan van deze wetgeving is slechts een enkele keer tot rechtsvervolging overgegaan. ${ }^{6}$ In een zaak uit 1968 oordeelde de Hoge Raad dat de wetgever met de term 'smalende' het opzet, ofwel '(...) het subjectieve element bij de verdachte tot uitdrukking heeft willen brengen'. ${ }^{7}$ Dit betekent dat de verdachte de intentie moet hebben gehad het als 'reëel gestelde hoogste Opperwezen neer te halen', ${ }^{8}$ hetgeen lastig te bewijzen is door het Openbaar Ministerie. Na dit arrest heeft het godslasteringsverbod zijn wezenlijke functie verloren en is het in onbruik geraakt. ${ }^{9}$ Het verbod is echter, onverminderd een kleine wijziging, ${ }^{10}$ tot 3 december 2013 van kracht gebleven. Er is toen gevolg gegeven aan het initiatiefvoorstel uit 2009 om artikelen 147 en 147a Sr inzake het verbod op smalende godslastering te schrappen. ${ }^{11}$ Het voorstel is uiteindelijk in 2014 tot voltooiing gebracht. ${ }^{12}$

De onderbouwing van het wetsvoorstel rust op diverse argumenten. Een daarvan is dat ondanks het functieverlies van de wetsartikelen na dit zojuist genoemde arrest, nog steeds de mogelijkheid bestaat om een beroep te doen op de godslasteringsbepalingen. ${ }^{13}$ Voorts wijst men op de onduidelijkheid van het te beschermen goed, omdat de definitie van 'God' niet helder is. ${ }^{14}$ De initiatiefnemers stellen daarnaast dat de neutraliteit van de staat in het geding komt als deze gedwongen wordt hierover een standpunt in te nemen, waarbij tegelijkertijd de gelijke behan-

6 Kamerstukken II 2009/10, 2203, 3, 4.

7 HR 2 april 1968, NJ 1968/373.

8 HR 2 april 1968, NJ 1968/373; Plooy, Strafbare godslastering, 77.

9 Plooy, Strafbare godslastering, 83; Van Stokkom, Sackers en Wils, Godslastering, discriminerende uitingen wegens godsdienst en haatuitingen, 109.

10 Stb. 1984, 91, in werking getreden op 1 mei 1984 vanwege de invoering van de boetecategorieën.

11 Kamerstukken II 2009/10, 32203, 2.

12 Handelingen I 2013/14, 11, item 5, 28-29.

13 Kamerstukken II 2009/10, 32203, 3, 6-7.

14 Kamerstukken II 2009/10, 32203, 3, 7. 
deling van godsdiensten en levensbeschouwingen onder druk komt te staan. Verder wijzen zij op de bestaande mogelijkheden van artikelen 137c t/m 137e Sr, die geschikter zijn om haatzaaiende, discriminerende en beledigende uitingen te bestrijden dan de artikelen 147 en $147 a$ Sr. $^{15}$ Ten slotte menen de initiatiefnemers dat het verbod op smalende godslastering onnodig is om verstoringen van de openbare orde tegen te gaan en is het aan het maatschappelijk debat om hier uitkomst in te bieden. ${ }^{16}$

In de volgende paragrafen zullen deze argumenten geanalyseerd en geëvalueerd worden en zullen diverse andere argumenten uiteengezet en toegelicht worden die pleiten voor een definitieve afschaffing van het godslasteringsverbod. Hiervoor zal eerst worden ingegaan op de positie van godsdienstige tegenover nietgodsdienstige beschouwingen die besproken is in de academische discussie.

\section{Een bijzondere positie voor gelovigen?}

Een eerste probleem met artikel $147 \mathrm{Sr}$ is dat dit tot een ongelijke waardering leidt van enerzijds godsdienstige en anderzijds levensbeschouwelijke opvattingen. ${ }^{17}$ Dit was, zoals hierboven al bleek, een belangrijke reden om het initiatiefwetsvoorstel in te dienen. Het argument dat godsdienstige opvattingen een facet zouden kennen dat andersoortige opvattingen missen wordt niet aanvaard, daar het niet duidelijk is dat een scherpe scheidslijn tussen religieuze en niet-religieuze overtuigingen kan worden getrokken. ${ }^{18} \mathrm{Als}$ een dergelijke lijn al te trekken valt, zou dit bovendien niet op wettelijke gronden kunnen worden gedaan. ${ }^{19}$ De wet, althans in een niet-totalitair systeem, kan immers slechts bepalen hoe men met bepaalde zaken omgaat en niet wat de inhoud daarvan is (of zou moeten zijn). Een discussie of godsdienstige gevoelens aan de orde zijn zou al snel verzanden in een theologisch onderzoek, dat de gemiddelde parlementariër - of rechter - niet op zich kan nemen, temeer daar over diverse kwesties zelfs experts en gelovigen zelf geen eensgezinde positie innemen. Hierop wijzen ook Nieuwenhuis en Janssens, die hieraan toevoegen dat '(...) sterk afwijkende opvattingen eerder met het strafrecht in aanmerking kunnen komen dan uitlatingen van de goegemeente.'20 Overigens is het opvallend dat artikelen 145 en 146 Sr wél een gelijke behandeling kennen van godsdienstige en niet-godsdienstige opvattingen. ${ }^{21}$ (Art. 145 en 146 Sr zien respectievelijk op het verhinderen en het storen van een godsdien-

15 Wij zullen hieronder veelal alleen naar art. 147 Sr verwijzen; wat we stellen is, mutatis mutandis, ook van toepassing op art. 147 a Sr.

16 Kamerstukken II 2009/10, 2203, 3, 7-11.

17 Hier worden 'godsdienstige' tegenover 'levensbeschouwelijke' opvattingen gesteld, niet omdat godsdienstige opvattingen niet van dien aard zouden zijn, maar omdat dit onderscheid door de wetgever wordt gemaakt, bijvoorbeeld in art. 145 en $146 \mathrm{Sr}$.

18 Kamerstukken II 2009/10, 32203, 4, 9; Jasper Doomen, Freedom and Equality in a Liberal Democratic State (Gent: Bruylant, 2014), par. 10.9, 118, 119.

19 Vgl. Koo van der Wal, 'Is de vrijheid van godsdienst in de moderne multiculturele samenleving nog een hanteerbaar recht?,' Netherlands Journal of Legal Philosophy 39 (2010): 135, 154.

20 Aernout Nieuwenhuis en Alfred Janssens, Uitingsdelicten (Deventer: Kluwer, 2011), 336.

21 Kamerstukken II 2011/12, 32203, 7, 4. 
stige of levensbeschouwelijke openbare samenkomst of (lijk)plechtigheid.) $\mathrm{Nu}$ zien de artikelen wel op verschillende aspecten, maar deze discrepantie lijkt toch moeilijk te verdedigen. Hieronder zullen we op dit punt terugkomen.

In een analyse van artikel 147 Sr stelt De Beer dat het voor de overheid niet relevant zou moeten zijn of een godsdienstig element in de bespotting of beschimping ligt. ${ }^{22}$ Het is de vraag of dit juist is. Gelovigen voeren vaak aan dat een belangrijk aspect zo onvoldoende wordt belicht, namelijk het belang dat religie voor de religieuze persoon heeft. De Blois verwoordt het als volgt: 'We kunnen (...) godsdienst en levensovertuiging niet zonder meer gelijkstellen met zomaar een mening die wordt beschermd door de vrijheid van meningsuiting. Het gaat om samenhangende opvattingen van een fundamenteel karakter, die direct te maken hebben met wat het meest wezenlijke is voor het mens-zijn. Het betreft - als het gaat om een godsdienstige overtuiging - (...) de relatie van de mens tot zijn Schepper of tot een hogere macht. (...) Het gaat - in een niet-godsdienstige overtuiging - om (...) het samenstel van overtuigingen die richting en zin geven aan het bestaan, soms gebaseerd op publicaties van belangrijke denkers. ${ }^{23}$

Ten eerste worden godsdienstige en niet-godsdienstige opvattingen hier samen gecontrasteerd met 'zomaar een mening', ${ }^{24}$ wat het verschil tussen de twee soorten opvattingen slechts problematiseert, tenzij men artikel $147 \mathrm{Sr}$ niet alleen zou willen behouden (of op een andere wijze gestalte geven), maar zelfs zodanig uitbreiden dat ook de niet-godsdienstige opvattingen (en de daarmee gepaard gaande gevoelens) zouden worden beschermd. Het zou wel consequent zijn, maar tot een eigen problematiek leiden, die in paragraaf 3 zal worden behandeld. Ten tweede gaat het om datgene wat (voor de gelovige) als zinvol wordt ervaren. De Blois neemt hier een gematigd standpunt in, maar door sommigen wordt godsdienst op dit punt als iets zodanig bijzonders gezien dat het een status aparte zou moeten hebben. Zo zegt Vermeulen dat godsdienstige overtuigingen, in ieder geval voor de gelovigen, van een hogere orde zijn, waarbij het gaat om het feit dat deze ten grondslag liggen aan het eigen bestaan en richtpunten zijn voor een zinvol leven. ${ }^{25}$ Hieraan voegt hij toe dat 'het overkoepelende zingevende en identiteitsbepalende karakter van religie' het specifieke is van de godsdienstige dimensie. $^{26}$

22 Paul de Beer, 'Waarom vrijheid van godsdienst uit de grondwet kan,' Socialisme en Democratie 64 (2007): 22.

23 Matthijs de Blois, 'Vóór godsdienstvrijheid,' in Hana van Ooijen et al. (red.), Godsdienstvrijheid: afschaffen of beschermen? (Leiden: NJCM-Boekerij, 2008), 34.

24 Elders betoogt De Blois juist dat er belangrijke verschillen bestaan: 'Gelijke behandeling is in het geding wanneer het om gelijke gevallen gaat. Het lijkt mij evident dat gelovigen en ongelovigen in het verband van de godslastering niet aan elkaar gelijk zijn. Het Godsgeloof dat de gelovigen aanhangen ontbreekt bij de ongelovigen. Ongelovigen kunnen niet klagen over het feit dat zij niet worden beschermd tegen krenking van gevoelens die zij niet hebben.' Matthijs de Blois, 'Smalende godslastering,' in Matthijs de Blois et al. (red.), Vloeken als een Hollander. Godslastering: religieuze, juridische en culturele aspecten (Amsterdam: Buijten en Schipperheijn Motief, 2007), 24.

25 Ben Vermeulen, 'Waarom de vrijheid van godsdienst niet geschrapt mag worden,' in Hana van Ooijen et al. (red.), Godsdienstvrijheid: afschaffen of beschermen? (Leiden: NJCM-Boekerij, 2008), 20.

26 Vermeulen, 'Waarom de vrijheid van godsdienst niet geschrapt mag worden,' 21. 
Het valt echter moeilijk in te zien waarom zingeving alleen ervaren zou kunnen worden vanuit een religieuze overtuiging. ${ }^{27}$ Schutgens merkt dan ook terecht op: 'Ook areligieuze en antireligieuze overtuigingen komen voor én kunnen voor degenen die deze opvattingen aanhangen diepgevoeld, fundamenteel en zingevend zijn.' 28 Het communisme, bijvoorbeeld, kan voor sommigen een zingevend geheel zijn. Zo stellen we met Sager vast: 'There simply is no good reason for offering religion a priority over other deep passions and commitments. ${ }^{29}$

Een aanvullend probleem is dat afwijkende opvattingen snel problematisch kunnen worden: als geloofsopvattingen bijzondere bescherming ontvangen, wordt de indruk gewekt dat deze niet bekritiseerd mogen worden, wat ertoe kan leiden dat degenen die dat wel doen ervan beschuldigd kunnen worden dat ze discrimineren. ${ }^{30}$ Dit gevaar wordt weliswaar gematigd door het feit dat het om 'smalende godslasteringen op voor godsdienstige gevoelens krenkende wijze' moet gaan, maar blijft reëel.

\section{Godsdienstvrijheid}

De indruk kan ontstaan dat deze discussie een zuiver academische is. Dat is niet het geval; nu komt dan ook de vraag aan de orde wat het praktisch zou uitmaken als niet alle opvattingen gelijk zouden worden behandeld.

De openbare orde wordt aangevoerd als een van de redenen om artikel $147 \mathrm{Sr}$ te rechtvaardigen. ${ }^{31}$ De initiatiefnemers stellen echter dat '(...) de artikelen over smalende godslastering in ieder geval de afgelopen decennia niet noodzakelijk dan wel bruikbaar zijn gebleken voor het handhaven van de openbare orde, waardoor niets zich ertegen verzet om deze artikelen [artikelen 147, 147a en 429bis Sr] te schrappen. ${ }^{32}$ Afgezien daarvan '(...) zijn er (...) buiten het strafrecht mogelijkheden ter voorkoming van verstoring van de openbare orde. ${ }^{\text {'3 }}$

Ondertussen kan men betogen dat 'openbare orde' niet, of niet alleen, in negatieve zin moet worden begrepen, namelijk als het domein waar de overheid niet ingrijpt, maar in positieve zin, waarbij het gaat om het garanderen van de moge-

27 Strikt genomen wordt gezegd dat het zingevende karakter van religie alleen aan de orde is bij de godsdienstige dimensie, maar dat helpt de gelovige niet en is niet verhelderend, omdat hiertegenover gesteld kan worden dat het zingevende karakter van een niet-godsdienstige opvatting alleen aan de orde is bij de niet-godsdienstige dimensie. Een Boeddhist (voor zover het Boeddhisme niet als religie wordt aangemerkt) of humanist kan menen dat het zingevende karakter van zijn opvatting slechts binnen die dimensie kan blijken.

28 Roel Schutgens, 'Waarom de godsdienst- en de uitingsvrijheid moeten samensmelten,' Tijdschrift voor Constitutioneel Recht 3 (2012): 97.

29 Lawrence Sager, 'The Moral Economy of Religious Freedom,' in Peter Cane et al. (red.), Law and Religion in Theoretical and Historical Context (Cambridge: Cambridge University Press, 2008), 18.

30 Rebecca Ross, 'Blasphemy and the Modern, “Secular” State,' Appeal 17 (2012): 8.

31 Piet Hein van Kempen, 'Religie in het Wetboek van Strafrecht,' in Hansko Broeksteeg en Ashley Terlouw (red.), Overheid, recht en religie (Deventer: Kluwer, 2011), 170, 174.

32 Kamerstukken II 2009/10, 32203, 3, 9.

33 Kamerstukken II 2009/10, 32203, 3, 9. 
lijkheid om het geloof te belijden. ${ }^{34}$ Het gaat dan om de vraag of godsdienstvrijheid moet worden gezien als negatieve vrijheid (men wordt vrijgelaten om zijn geloof te belijden) of als positieve vrijheid (de overheid draagt middelen aan om dit te faciliteren).

Het is duidelijk dat de initiatiefnemers godsdienstvrijheid in de eerste zin begrijpen. ${ }^{35}$ Een dergelijk standpunt valt te verdedigen zolang men meent dat godsdienstvrijheid en vrijheid van meningsuiting kunnen samenvallen. ${ }^{36}$ De positie die men hier inneemt, hangt natuurlijk af van wat men onder 'belijden' verstaat; Nap betoogt bijvoorbeeld dat beide vrijheden naast elkaar moeten worden beschermd, vanuit de overweging dat 'belijden' niet kan worden gereduceerd tot het uiten van meningen. ${ }^{37}$ Inderdaad kan belijden niet zo reductionistisch opgevat worden. Het zou vreemd zijn om bijvoorbeeld het houden van erediensten of het om religieuze redenen dragen van een hoofddoek als het uiten van een mening te beschouwen. Het gaat immers om praktijken.

Daarmee is de kwestie echter slechts geduid; het valt nog te bezien welke gevolgen hieraan moeten worden verbonden. Het is namelijk niet noodzakelijk dat ruimte voor het belijden van het geloof met zich brengt dat artikel $147 \mathrm{Sr}$ moet worden gehandhaafd. Om te beginnen is er de reeds genoemde problematiek van de ongelijke behandeling tussen godsdienstige en niet-godsdienstige overtuigingen. Meijers stelt in dat licht voor om het artikel zodanig te herformuleren dat beide soorten overtuigingen worden beschermd, op dezelfde manier als in artikelen 145 en $146 \mathrm{Sr}$, zodat het bereik van het artikel wordt vergroot. ${ }^{38}$

Dit leidt echter tot een ander probleem: als artikel $147 \mathrm{Sr}$ in de huidige vorm al tot een inperking van de meningsvrijheid leidt, zal dit a fortiori het geval zijn bij een uitbreiding van het bereik van het artikel. Het zal ook tot interpretatieproblemen leiden: mag men niet meer smalend over Marx of Lenin spreken omdat dit communisten zou kunnen krenken? Bovendien lijkt dit het artikel zodanig te doen 'verwateren' dat de afwezigheid van de noodzaak ervan snel duidelijk wordt. Meijers voert zelf aan dat het Godsbeeld in zijn alternatief niet meer centraal staat, ${ }^{39}$ terwijl dit toch juist het kenmerkende van artikel $147 \mathrm{Sr}$ was. Als dit wordt opgegeven, lijken artikelen 137 c Sr e.v. voldoende om het beoogde doel te bereiken. De grens tussen het beschermen van de opvattingen zelf en de aanhangers daarvan is dan immers zodanig vervaagd dat de praktische uitkomst niet meer verschilt.

Ook voor gelovigen zelf kan het vervallen van artikel 147 Sr welkom zijn, hoe opmerkelijk dat in eerste instantie ook kan lijken. Zoals Ross opmerkt: 'Since situations of blasphemy are conflicts between two different religions or within one

Vgl. Ton Meijers, 'Het verbod op smalende krenkende godslastering: een legitieme strafbepaling?,' Nederlands Tijdschrift voor Kerk en Recht 1 (2007): 12.

35 Kamerstukken II 2009/10, 32203, 3, 9.

36 De Beer, 'Waarom vrijheid van godsdienst uit de grondwet kan,' 23; Schutgens, 'Waarom de godsdienst- en de uitingsvrijheid moeten samensmelten,' 99.

37 Mentko Nap, 'Waarom de vrijheid van godsdienst en de uitingsvrijheid niet kunnen samenvallen,' Tijdschrift voor Constitutioneel Recht 1 (2012), 100-101.

38 Meijers, 'Het verbod op smalende krenkende godslastering,' 15.

39 Meijers, 'Het verbod op smalende krenkende godslastering,' 15. 
religion, it is difficult to justify blasphemy on the basis of freedom of religion because one's freedom of religion may infringe another's by the mere fact that one holds a religious belief that contradicts another's. ${ }^{40} \mathrm{Zij}$ die vanuit een religieus perspectief belang menen te hebben bij het bestaan van artikel $147 \mathrm{Sr}$ moeten dan ook bedenken dat hun eigen vrijheid sterk ingeperkt wordt. Dergelijke confrontaties zijn bijna onvermijdelijk in een pluralistische samenleving. ${ }^{41}$

\section{Het bepalen van de grenzen van de vrijheden van godsdienst en meningsuiting}

Zoals hiervoor is aangegeven, moeten godsdienstvrijheid en vrijheid van meningsuiting worden onderscheiden. Vermeulen verwijst in dat licht naar het ritueel slachten, het naar de regels van een godsdienst sluiten van een huwelijk, het dragen van een hoofddoek en het niet geven van een hand om religieuze overwegingen. ${ }^{42}$ In het verlengde daarvan vraagt hij zich af of het dan wel om meningsuitingen gaat; het lijkt erop dat het begrip 'meningsuiting' te zeer wordt opgerekt. Deze uitleg zou alleen kunnen worden verdedigd door aan te geven dat het meningsuitingen betreft vanwege de religieuze dimensie en intentie, zodat het kwalificatieprobleem zich opnieuw voordoet. ${ }^{43}$

Als het in zulke gevallen niet gaat om meningsuiting, zoals we - met Vermeulen betogen, is het kwalificatieprobleem niet aan de orde. Wel resteert een ander probleem: het moet nog steeds duidelijk worden welke eventuele beperkingen hier aanvaardbaar zijn. Een klassiek criterium is het schadebeginsel. Mill formuleert het als volgt: '(...) the only purpose for which power can be rightfully exercised over any member of a civilized community, against his will, is to prevent harm to others. ${ }^{44}$ Hierbij moet bedacht worden dat gelovigen hierop een beroep kunnen doen, maar ook aangesproken kunnen worden op dezelfde grond (namelijk als ze zelf schade toebrengen aan anderen). De initiatiefnemers blijken zich op het schadebeginsel te baseren. ${ }^{45}$ Problematisch met dit beginsel is dat het vrij vaag is; het valt moeilijk vol te houden dat lichamelijk letsel er niet onder zou vallen, maar dat is slechts de ondergrens. ${ }^{46}$ Men kan zich dan ook, afhankelijk van de definitie van 'schade' die men hanteert, afvragen of deze bepaling toereikend is. ${ }^{47}$

Wat betreft de genoemde gevallen valt te betogen dat ze de toets van het schadebeginsel kunnen doorstaan; bij het dragen van een hoofddoek moet het dan uiteraard wel om een door de vrouw zelf gewilde situatie gaan. De kwestie van het ritu-

40 Ross, 'Blasphemy and the Modern, “Secular” State,' 18.

41 Jeroen Temperman, 'Freedom of Expression and Religious Sensitivities in Pluralist Societies: Facing the Challenge of Extreme Speech,' Brigham Young University Law Review 3 (2011): 730.

42 Vermeulen, 'Waarom de vrijheid van godsdienst niet geschrapt mag worden,' 20.

43 Vermeulen, 'Waarom de vrijheid van godsdienst niet geschrapt mag worden,' 20.

44 John Stuart Mill, On Liberty. Collected Works of John Stuart Mill, vol. 18 (Toronto: University of Toronto Press, 1977 [1859]), 223.

45 Kamerstukken II 2011/12, 32203, 7, 5.

46 Mill zelf lijkt op bepaalde plekken een brede notie van 'schade' te hanteren (On Liberty, 224, 260), maar laat onduidelijkheid bestaan over de precieze kwalificatie.

47 Doomen, Freedom and Equality in a Liberal Democratic State, par. 10.2, 109, 110. 
eel slachten is gecompliceerder, daar het om botsende belangen van (gelovige) mensen en dieren gaat; een wetsvoorstel om deze vorm van slachten te verbieden, is uiteindelijk in de Eerste Kamer gestrand. ${ }^{48}$

Het schadebeginsel kan ook worden toegepast op artikel 147 Sr. Eerst moet worden bepaald of gelovigen worden geschaad. Er is geen sprake van fysieke schade, maar zoals gezegd is dat slechts de ondergrens. Gelovigen kunnen werkelijk schade ondervinden - al gaat het dan niet om de meest ernstige vorm - als hun Godsconceptie wordt beschimpt. Dit betekent echter niet dat artikel $147 \mathrm{Sr}$ moet blijven bestaan. In een pluralistische samenleving mag van zowel niet-gelovigen als gelovigen worden gevraagd dat ze een zekere tolerantie opbrengen. Bovendien kunnen ze eventuele godslasteringen normaliter uit de weg gaan: niemand dwingt ze om boeken te lezen of televisie-uitzendingen te bekijken waarin dit aan de orde is. Overigens kan het schadebeginsel ook gehanteerd worden bij het interpreteren van artikelen 137c Sr e.v., maar dat laten we hier rusten; de initiatiefnemers betrekken deze artikelen niet in hun voorstel.

Steeds moet worden bedacht dat het om een belangenafweging gaat, waarbij het verbieden van godslastering de vrijheid van meningsuiting beperkt; een duidelijke en algemeen aanvaardbare grens van deze vrijheid, die op basis van het schadebeginsel, of een uitwerking daarvan, kan worden bereikt, is te verkiezen boven het simpelweg verbieden. Dat deze grens duidelijk zou zijn, lijdt geen twijfel; wij menen echter dat dit niet opgaat voor de vraag of deze ook algemeen aanvaardbaar zou zijn. ${ }^{49}$

Hoe dan ook vormt het schadebeginsel geen beletsel - en zelfs een motivatie - om artikel $147 \mathrm{Sr}$ te schrappen. Steeds moet schade, hoe dat ook wordt gedefinieerd, zo veel mogelijk worden voorkomen, maar voor een beperking van de meningsvrijheid is een grotere rechtvaardiging nodig dan voor een beroep op degenen die zich aangesproken (kunnen) voelen om te proberen deze schade te vermijden; dat ze daartoe in de gelegenheid zijn is net zo zeer een verworvenheid als de vrijheden van meningsuiting en godsdienstvrijheid zelf dat zijn.

\section{Recente initiatieven in het wetgevingsproces}

Op basis van het voorafgaande kan gesteld worden dat de schrapping van het godslasteringsverbod geduid kan worden als een positieve ontwikkeling in de richting van een meer neutrale overheid en een striktere scheiding van kerk en staat. De motie-Schrijver c.s. die is aangenomen bij de schrapping van het verbod op 3 december 2013 doet dan ook de nodige vraagtekens rijzen bij de motieven van de Eerste Kamer. De Kamer geeft met de aanvaarding van deze motie een

48 Kamerstukken I 2011/12, 31571.

49 Vgl. András Koltay, Freedom of Speech: The Unreachable Mirage (Budapest: Complex, 2013), 180: '(...) any kind of restriction of blasphemy is unjustified, because, for example, it is hard to fit it in with the other rules of the legal system pertaining to freedom of speech, as we have decided that the standards of legal restrictions must generally be set high because we believe that we lose more than we gain with the restriction, or because we are very simply unable to determine the scope of those subjects worthy of protection.' 
ambigu signaal af, aangezien de regering hiermee verzocht wordt '(...) te onderzoeken of een mogelijke aanpassing van artikel 137c t/m h Sr dienstig kan zijn om te bewerkstelligen dat dit artikel eveneens genoegzame bescherming biedt tegen als ernstig ervaren belediging van burgers door belediging van hun geloof en geloofsbeleving, zonder de werking van de vrijheid van meningsuiting onnodig te beperken'. ${ }^{50}$ Een aantal punten in deze motie zijn opvallend.

Ten eerste wordt uit de toelichting niet duidelijk wat bedoeld wordt met 'geloof en geloofsbeleving', 'eveneens genoegzame bescherming', 'als ernstig ervaren belediging' en 'onnodig beperken'. Dit doet de vraag opkomen wat verstaan wordt onder deze concepten, daar een toelichting in de Handelingen ontbreekt en de betekenis vooralsnog onhelder blijft. ${ }^{51}$ De invulling van een van deze concepten, te weten de belediging van 'geloof', is reeds uitgesponnen in het debat. De Hoge Raad heeft zich immers op 10 maart 2009 uitgesproken over de reikwijdte van artikel 137c Sr. De Hoge Raad oordeelde dat het artikel strafbaar stelt "het zich beledigend uitlaten "over een groep mensen wegens hun godsdienst", doch niet het zich beledigend uitlaten over een godsdienst, ook niet indien dit geschiedt op zo'n wijze dat de aanhangers van die godsdienst daardoor in hun godsdienstige gevoelens worden gekrenkt'. ${ }^{52}$ De strekking van dit arrest is helder: alleen de directe discriminatoire belediging is strafbaar onder artikel $137 \mathrm{c} \mathrm{Sr} ;{ }^{53}$ het kwetsen van religieuze gevoelens door godsdienstkritiek valt buiten het bereik ervan. ${ }^{54}$ Evenzeer moet worden nagegaan wat onder 'geloofsbeleving' valt. Dit wordt gewoonlijk omschreven als het gevoelsaspect van het geloof dat voornamelijk is gegrond in de ervaring van de gelovige met zijn of haar God. Dit gevoelsaspect is louter persoonlijk en daarmee subjectief van aard; dit te willen benadrukken, vormt een opmerkelijk contrast met de huidige (strafrecht)doctrine, waarin immers gepleit wordt voor meer objectivering.

Dit argument van de subjectiviteit gaat tevens op voor de overige aangehaalde concepten. Met betrekking tot het concept van 'genoegzame bescherming' dient men zich af te vragen waar dan de grens van 'genoegzaam' ligt, aangezien deze voor elke gelovige anders is. Wanneer wordt een gelovige genoegzaam beschermd? Dit geldt eveneens voor de 'als ernstig ervaren belediging'. Wanneer wordt de godslasterende uitlating als ernstig ervaren?

Bovendien is door het Wetenschappelijk Onderzoek- en Documentatiecentrum (WODC) al onderzoek gedaan naar een mogelijke aanpassing van artikel 137c e.v Sr. Dit is namelijk aan de orde geweest in het onderzoek naar een mogelijke uit-

51 Handelingen I 2013/14, 10, item 2, 2-21; Handelingen I 2013/14, 10, item 12, 44-65 en Handelingen I 2013/14, 11, item 5, 28-29.

52 HR 10 maart 2009, ECLI:NL:HR:2009:BF0655, NJ 2010/19, m.nt. Mevis, r.o. 2.5.1.

53 Gelijn Molier, 'De vrijheid van meningsuiting: it's politics all the way down,' in Afshin Ellian et al. (red.), Mag ik dit zeggen? Beschouwingen over de vrijheid van meningsuiting (Den Haag: Boom Juridische uitgevers, 2011), 221-3.

54 Esther Janssen en Aernout Nieuwenhuis, 'De verhouding tussen vrijheid van meningsuiting en discriminatie in het Wilders-proces. Een analyse van "het proces van de eeuw", NTM/NJCMBulletin 37 (2012): 185. 
breiding van de godslasteringsdelicten na de moord op Theo van Gogh in 2004. ${ }^{55}$ De uitkomsten van dit onderzoek zijn duidelijk: 'Indien religiekwetsingen nodeloos grievend zijn, uitsluitend het kwetsen als doel hebben en (dus) geen functie hebben in het maatschappelijk debat, behoeft het strafrecht niet tandeloos toe te zien. Uitwassen van onverdraagzaamheid kunnen strafrechtelijk worden bestreden. Artikelen 137c en volgende Sr hebben deze functie en niets verzet zich ertegen ook daadwerkelijk op basis daarvan te vervolgen. ${ }^{56}$

Daarnaast kan betoogd worden dat een aanpassing van artikel 137c Sr t/m h indruist tegen hetgeen de initiatiefnemers trachten te bewerkstelligen met de schrapping van artikel $147 \mathrm{Sr}$, te weten een meer neutrale overheid en een verbreding van de vrijheid van meningsuiting. ${ }^{57}$ Dit zal niet meer aan de orde zijn wanneer er opnieuw, echter nu in een ander wetsartikel verankerd, een status aparte wordt toegekend aan religie. Het vervallen van artikel $147 \mathrm{Sr}$ zou dan niet meer zijn dan godslastering in een nieuw jasje steken. Fractieleider De Lange van de Onafhankelijke Senaatsfractie in de Eerste Kamer verwoordt het wat vernuftiger: '(...) in de voorliggende motie wordt in feite voorgesteld de duivel van artikel 147 uit te drijven met de Beëlzebub van het mogelijk wijzigen van artikel 137. De motie impliceert namelijk dat de ongewenste en onterechte asymmetrie die artikel 147 kenmerkt, nu alsnog in artikel 137 terecht kan komen. ${ }^{58}$

Om deze redenen is het van belang dat de Eerste Kamer zich realiseert welke beweging in gang is gezet. Hierbij is het de vraag wat de Eerste Kamer wil bereiken met dit standpunt en, in het licht van wat in de volgende paragraaf gesteld wordt, wat hiervan de gevolgen zullen zijn voor de betekenis van de vrijheid van meningsuiting die Nederland naar de rest van de wereld uitdraagt. Door een dergelijk standpunt ten aanzien van godsdienstvrijheid in te nemen, worden landen waar godslastering tot zware straffen kan leiden immers in de kaart gespeeld. Onder verwijzing naar artikel 137c e.v. Sr, op grond waarvan dan het kwetsen van religieuze gevoelens strafbaar zou worden gesteld, kunnen dergelijke landen dan een rechtvaardiging vinden voor hun beleid. Hierdoor zal Nederland op het terrein van de vrijheid van godsdienst en levensovertuiging niet alleen haar voorbeeldfunctie verliezen, maar ook haar geloofwaardigheid in de promotie hiervan in landen waar dit recht onder druk staat. Dit zal het realiseren van de missie van de Nederlandse mensenrechtenambassadeur Lionel Veer, die voor deze taak is aangesteld, aanzienlijk bemoeilijken. ${ }^{59}$ In de volgende paragraaf zal dit punt nader aan de orde komen. Ten slotte is het opvallend dat Nederland na de afschaffing van het blasfemieverbod door de International Humanist and Ethical Union de hoogste status is toegekend met betrekking tot het realiseren van de

Kamerstukken II 2004/05, 29854, 3, 8; Van Stokkom, Sackers en Wils, Godslastering, discriminerende uitingen wegens godsdienst en haatuitingen, 5; Kamerstukken I 2013/14, 32203, C, 4. Zie onder meer Paul Cliteur, 'Godslastering en zelfcensuur na de moord op Theo van Gogh,' NJB 45/46 (2004): 2328-35.

56 Van Stokkom, Sackers en Wils, Godslastering, discriminerende uitingen wegens godsdienst en haatuitingen, 137.

57 Kamerstukken II 2009/10, 32203, 3, 1-2, 7.

58 Handelingen I 2013/14, 11, item 5, 28-29.

59 Rijksdocument 'Mensenrechtenambassadeur,' december 2010, 1. 
vrijheden van godsdienst en meningsuiting. ${ }^{60}$ Dit is een navolgenswaardige positie voor andere staten, die waarschijnlijk verloren zal gaan als artikelen 137c e.v. Sr gewijzigd worden.

\section{Een internationaal perspectief}

Een belangrijk argument voor de definitieve afschaffing van het godslasteringsverbod dat in de parlementaire discussie onvoldoende benadrukt wordt, is gelegen in de internationale dimensie. Het schrappen van het verbod op godslastering in Nederland is namelijk kenmerkend voor het Europese standpunt in de discussie aangaande de defamatie van religies binnen de Verenigde Naties (VN). Om dit punt helder te maken is het van belang om eerst stil te staan bij het globale dan wel internationale concept waaronder godslastering geschaard wordt, te weten de 'defamation of religions'.

De Organization of Islamic Cooperation (OIC), de grootste internationale organisatie na de $\mathrm{VN}$, is een intergouvernementeel orgaan dat thans uit 57 lidstaten bestaat. De OIC dient reeds sinds 1999 resoluties in bij onder andere de Mensenrechtenraad (voorheen de Mensenrechtencommissie) en de Algemene Vergadering in het kader van 'defamation of religions'. ${ }^{61}$ Zo zijn er tientallen resoluties aangenomen waarin wordt opgeroepen om defamatie dan wel het lasteren van religies tegen te gaan. ${ }^{62}$ In de resoluties staat onder andere centraal: '(...) the enactment or strengthening of domestic frameworks and legislation to prevent the defamation of religions', 63 'stressing (...) the need to effectively combat defamation of all religions (...)'64 en '(...) the right to freedom of expression, (...) may be subject to limitations as provided by law and necessary for (...) respect for religions and beliefs'. ${ }^{65}$ Deze defamatieresoluties behelzen derhalve de oproep aan staten om strenge maatregelen te treffen die de vrijheden van godsdienst en meningsuiting legitiem beperken. Hierbij wordt niet alleen opgeroepen tot censuur, maar tevens om wetgeving te ontwikkelen waarin godslastering strafbaar is gesteld, oftewel handelingen die een dreigende dan wel discriminerende uitwerking hebben op critici en andersdenkenden. ${ }^{66}$ In landen die deel uitmaken van de

60 Vergelijk Freedom of Thought 2012. A Global Report on Discrimination against Humanists, Atheists and the Nonreligious (Londen: International Humanist and Ethical Union, 2012) met Matt Cherry, Freedom of Thought 2013. A Global Report on Discrimination against Humanists, Atheists and the Nonreligious (Londen: International Humanist and Ethical Union, 2013).

61 Onder andere resoluties 1999/82, 2000/84, 2001/4, 2002/9, 2003/4, 2004/6, 2005/3 van de Mensenrechtencommissie, resoluties 4/9, 7/19 van de Mensenrechtenraad en resoluties 60/150, 61/164, 62/154, 63/3, 64/156, 65/224 van de Algemene Vergadering (niet-limitatief).

62 Brett Scharffs, 'International Law and the Defamation of Religion Conundrum,' The Review of Faith and International Affairs 2 (2013): 66-69.

63 Resolutie 64/156 van de Algemene Vergadering van de Verenigde Naties (8 maart 2010), Combatting defamation of religions, UN Doc A/RES/64/156, onder 19, 6.

64 Resolutie Mensenrechtenraad (25 maart 2000), UN Doc A/RES/13/16, 2.

65 Resolutie 61/164 van de Algemene Vergadering van de Verenigde Naties (21 februari 2007), Combatting defamation of religions, UN Doc A/RES/61/164, onder 9, 3.

66 Heiner Bielefeldt, 'Misperceptions of Freedom of Religion or Belief,' Human Rights Quarterly 35 (2013): 41-42. 
OIC zijn deze strafbaarstellingen reeds een gegeven; zo is in Pakistan, een van de toonaangevende land binnen de OIC, op 24 maart 2014 een man door de rechtbank wegens godslastering tot de doodstraf veroordeeld. ${ }^{67}$

Daarnaast wordt in de defamatieresoluties de nadruk gelegd op de bescherming van godsdiensten. Hoewel het duidelijk is dat het hierbij gaat om bescherming van de islam, is het niet helder aan wie deze bescherming in de praktijk toekomt. Gaat het hier om de heersende staatsreligie in het land, de religieuze gezaghebbers of wellicht de meerderheid van de gelovigen ${ }^{68}$ Afgezien daarvan is het idee van de bescherming van godsdiensten overduidelijk in strijd met het acquis van de mensenrechten, waarin het individu en de vrijheid centraal staan. ${ }^{69}$

De resoluties zijn dan ook niet zonder weerstand ontvangen binnen de VN; ze leidden tot hevige discussies tussen de OIC en de Europese staten, waaronder Nederland en tijdens de Deense cartooncrisis in 2006 bereikte dit een hoogtepunt. ${ }^{70}$ In grote delen van de islamitische wereld waren er hevige protesten; de mensen aldaar voelden zich beledigd door de cartoons en hun oproep om dit soort laster te bestrijden werd door de OIC vorm gegeven in dergelijke resoluties. ${ }^{71}$ Ondanks de weerstand en het verzet tegen de resoluties door de aanwezige Europese staten wist de OIC steevast een meerderheid van de stemmen te bemachtigen. ${ }^{72}$

$\mathrm{Na}$ jaren van hevig debat binnen de diverse VN-organen vindt er in 2011 een kentering plaats. De OIC dient bij de Mensenrechtenraad resolutie 16/18 in, inzake 'Combating intolerance, negative stereotyping and stigmatization of, and discrimination, incitement to violence and violence against persons based on religion or belief. ${ }^{73}$ Deze resolutie is met consensus op 24 maart 2011 aangenomen en fungeert sindsdien als leidend document voor besprekingen binnen de VN. Hoewel er nog veel haken en ogen kleven aan deze resolutie, ontbreekt een expliciete verwijzing naar defamatie van religies en lijkt het doel niet de bescherming van de reputaties van godsdiensten, maar bescherming van het individu; een doel dat meer in overeenstemming is met het mensenrechtenacquis. ${ }^{74}$

67 Waqar Gillani en Salman Masood, 'Pakistani Gets Death Penalty for Blasphemy,' The New York Times, 27 maart 2014; 'Pakistan Court Sentences Christian Man to Death for Blasphemy,' The Guardian, 27 maart 2014.

68 Bielefeldt, 'Misperceptions of Freedom of Religion or Belief,' 41-42.

69 L. Bennett Graham, 'Defamation of Religions: The End of Pluralism?,' Emory International Law Review 23 (2009): 72; Scharffs, 'International Law and the Defamation of Religion Conundrum,' 69; Bielefeldt, 'Misperceptions of Freedom of Religion or Belief,' 42-43 en Temperman, 'Freedom of Expression and Religious Sensitivities in Pluralist Societies,' 730.

70 Bielefeldt, 'Misperceptions of Freedom of Religion or Belief,' 41-42.

71 Zie Paul Cliteur, The Secular Outlook: In Defense of Moral and Political Secularism (Chichester: Wiley-Blackwell, 2010), 146-7, 163-6.

72 Robert Blitt, 'Defamation of Religion: Rumors of its Feath Are Greatly Exaggerated,' Case Western Reserve Law Review 62 (2011): 352-5 en Bielefeldt, 'Misperceptions of Freedom of Religion or Belief,' 41-42.

73 Resolutie 16/18 van de Mensenrechtenraad van de Verenigde Naties (24 maart 2011), Combating Intolerance, Negative Stereotyping and Stigmatization of, and Discrimination, Incitement to Violence and Violence Against, Persons Based on Religion or Belief, UN Doc A/RES/16/18.

Bielefeldt, 'Misperceptions of Freedom of Religion or Belief,' 41-43. 
In de internationale gemeenschap is de 16/18-resolutie dan ook met goedkeuring ontvangen. Deze is door Bielefeldt, de Speciale Rapporteur voor Vrijheid van Godsdienst en Geloof van de VN, omschreven als een 'positive development'75 en ook Hillary Clinton, voormalig minister van Buitenlandse Zaken van de Verenigde Staten, prijst de resolutie en stelt dat het een 'significant step forward'76 is. In eerste instantie lijkt dit dan ook een stap vooruit te zijn; de intentie om met deze resolutie de strafbaarstelling van defamatie van religies los te laten, wordt echter niet door alle landen onderschreven. De OIC-landen blijken namelijk een andere inhoud dan wel uitvoering uit de tekst af te leiden dan de Europese staten. Bovendien verbindt de OIC de 16/18-resolutie met de voorgaande defamatieresoluties en stelt dat het niet meer was dan 'exploring [an] alternative approach (...) ${ }^{77}$ en dat zij '(will) continue to explore options with regard to broadening support for the resolution on defamation of religions (...)'. ${ }^{78}$ Hieruit wordt duidelijk dat de Europese staten en de landen van de OIC op dit moment nog sterk uiteenlopende opvattingen hebben.

Hoewel in het algemeen de regeringen in het Westen tegen de defamatieresoluties stemden, is de mogelijkheid tot het uiten van smalende godslasteringen binnen Europa geen gegeven. Diverse Europese staten, waaronder Oostenrijk, Duitsland en Ierland, hebben immers wetgeving in hun rechtsbestel opgenomen dat godslastering strafbaar stelt. Zo is in Rusland op 1 juli 2013 nog een wet ingevoerd waarin het beledigen van religieuze gevoelens strafbaar is gesteld. ${ }^{79}$ Daarnaast kunnen enkele historische uitspraken van het Europese Hof van de Rechten van de Mens (EHRM) zo geïnterpreteerd worden dat religieuze gevoelens wettelijk beschermd moeten worden. Zo oordeelde het EHRM dat de vrijheid van meningsuiting door een lidstaat gerechtvaardigd beperkt kan worden indien er sprake is van godslasterende, kwetsende uitingen. ${ }^{80}$ Het Hof oordeelt dat '(...) it is not possible to arrive at a comprehensive definition of what constitutes a permissible interference with the exercise of the right to freedom of expression where such expression is directed against the religious feelings of others. A certain margin of appreciation is therefore to be left to the national authorities in assessing the existence and extent of the necessity of such interference'. ${ }^{81}$ De lidstaten wordt derhalve ruimte gelaten inzake de beoordeling van de overschrijding van grenzen bij het kwetsen van religieuze gevoelens.

75 Bielefeldt, 'Misperceptions of Freedom of Religion or Belief,' 43.

76 Kevin Eckstrom, 'Clinton Applauds U.N.'s Religious Freedom Resolution,' The Huffington Post, 25 maart 2011.

77 Resolutie 35/38 OIC (28-30 juni 2011), On Combating Defamation of Religions, Res. 35/38-POL, opgenomen in OIC/CFM-38/2011/POL/FINAL, 82.

78 Resolutie 35/38 OIC (28-30 juni 2011), On Combating Defamation of Religions, Res. 35/38-POL, opgenomen in OIC/CFM-38/2011/POL/FINAL, 82; Blitt, 'Defamation of Religion,' 361-5 en Javaid Rehman en Stephanie Berry, 'Is "Defamation of Religions" Passé? The United Nations, Organisation of Islamic Cooperation, and Islamic State Practices: Lessons from Pakistan,' The George Washington International Review 44 (2012): 451.

79 Zie voor meer over Rusland: Cherry, Freedom of Thought 2013, 195-7.

80 EHRM 20 september 1994, 13470/87, NJ 1995/366 (Otto-Preminger-Institut/Oostenrijk); EHRM 25 november 1996, 17419/90, NJ 1998/359 (Wingrove/Verenigd Koninkrijk).

81 EHRM 25 november 1996, 17419/90, NJ 1998/359 (Wingrove/Verenigd Koninkrijk), par. 50. 
Uit het voorgaande blijkt dat de rechtspraak van het EHRM en de toepassing van het internationale concept van 'defamation of religion' door het OIC afwijken van de Europese stellingname binnen de VN en het Nederlandse beleid. Vanuit dit perspectief is het schrappen van het Nederlandse verbod op godslastering derhalve niet alleen als voorbeeld stellend voor de rest van de wereld, maar is tevens een onderschrijving van het Europese standpunt binnen de VN. ${ }^{82}$ Door de schrapping van het godslasteringsverbod en het niet terug te laten keren in het Nederlandse recht wordt een nieuwe tendens ingezet, waarbij Nederland als voorbeeld kan fungeren voor de rest van de wereld en zich aan deze rol ook niet zou mogen onttrekken.

\section{Conclusie}

In dit artikel is de wenselijkheid van godslastering onderzocht, waarbij we een aantal recente ontwikkelingen in het recht, op zowel nationaal als internationaal niveau, hebben beschouwd. We hebben daarbij willen aantonen dat het strafbaar stellen van godslastering onwenselijk is en daartoe beargumenteerd dat de definitie van 'religie' problematisch is, zodat zelfs het bepalen van wat 'godslastering' zou moeten zijn al moeilijk is. Zelfs zonder dit probleem echter, moet bedacht worden dat de belangen van degenen die worden beschermd door een verbod op godslastering moeten worden afgewogen tegen het belang van de vrijheid van meningsuiting; wij hebben betoogd dat dit laatste belang moet prevaleren. Het is ondertussen de vraag of deze uitkomst met het afschaffen van artikel $147 \mathrm{Sr}$ wordt bereikt. De artikelen 137 e.v. Sr blijven immers bestaan en gelovigen zullen hierop een beroep kunnen doen. Daarbij is van belang dat de motie-Schrijver c.s. beoogt om deze artikelen zodanig aan te passen dat gelovigen tegen een 'als ernstig ervaren belediging' worden beschermd, waarmee opnieuw een bijzondere status zou worden toegekend aan religie en de neutraliteit van de staat wordt aangetast. Het is op die manier natuurlijk de vraag of met het schrappen van artikel $147 \mathrm{Sr}$ werkelijk iets bereikt wordt. Als we ons richten op de internationale dimensie blijkt dat godslastering in veel Europese én OIC-landen nog steeds strafbaar is, waarbij de OIC-landen zich blijven inzetten voor een internationale strafbaarstelling. Op basis van de in dit artikel gepresenteerde analyse menen wij dat Nederland in deze kwestie een voortrekkersrol kan (en moet) vervullen; het afschaffen van het godslasteringsverbod, zonder dit via de achterdeur opnieuw in te voeren, sluit daarbij aan. 